\title{
Morphology, Ultrastructure, and Mitochondrial Genome of the Marine Non-Photosynthetic Bicosoecid Cafileria marina Gen. et sp. nov.
}

\author{
Dagmar Jirsová $^{1,+} \mathbb{D}$, Zoltán Füssy ${ }^{1,2,+} \mathbb{D}$, Jitka Richtová ${ }^{1,2}$, Ansgar Gruber $^{1} \mathbb{D}$ and \\ Miroslav Oborník 1,2,* \\ 1 Institute of Parasitology, Biology Centre, Czech Academy of Sciences, Branišovská 31, \\ 37005 České Budějovice, Czech Republic \\ 2 Faculty of Science, University of South Bohemia, Branišovská 31, 37005 České Budějovice, Czech Republic \\ * Correspondence: obornik@paru.cas.cz; Tel.: +420-387775464 \\ + These authors contributed equally to this work.
}

Received: 26 June 2019; Accepted: 1 August 2019; Published: 5 August 2019

check for updates

\begin{abstract}
In this paper, we describe a novel bacteriophagous biflagellate, Cafileria marina with two smooth flagellae, isolated from material collected from a rock surface in the Kvernesfjorden (Norway). This flagellate was characterized by scanning and transmission electron microscopy, fluorescence, and light microscopy. The sequence of the small subunit ribosomal RNA gene (18S) was used as a molecular marker for determining the phylogenetic position of this organism. Apart from the nuclear ribosomal gene, the whole mitochondrial genome was sequenced, assembled, and annotated. Morphological observations show that the newly described flagellate shares key ultrastructural characters with representatives of the family Bicosoecida (Heterokonta). Intriguingly, mitochondria of C. marina frequently associate with its nucleus through an electron-dense disc at the boundary of the two compartments. The function of this association remains unclear. Phylogenetic analyses corroborate the morphological data and place $C$. marina with other sequence data of representatives from the family Bicosoecida. We describe C. marina as a new species from a new genus in this family.
\end{abstract}

Keywords: heterotrophic nano-flagellate; heterokonta; bicosoecida; phylogeny; flagellar apparatus; new genus

\section{Introduction}

Heterotrophic flagellates are one of the cornerstones of aquatic ecosystems, as they are the prime bacterial consumers in the microbial food web and they are among the most important nutrient remineralizers and intermediators to higher levels of the trophic cascade [1,2]. These organisms inhabit a variety of ecosystems, including low-level oxygen or anoxic bottom waters [3-5], deep-sea sediments [6], and hypersaline environments [7]. Free-living heterotrophic and mixotrophic stramenopiles represent an important part of pelagic food webs, due to their capability to consume bacteria or dissolved organic material. Moreover, in some habitats, they represent about one third of all heterotrophic flagellates and thus, majorly contribute to a big part of nutrient recycling in the environment $[8,9]$.

Stramenopiles are a highly variable group ranging from heterotrophic nanoprotists to giant phototrophic multicellular kelps [10-12]. Stramenopila can be divided into obligate heterotrophs, the apparently plastid-less labyrinthulomycetes, oomycetes, opalinids, and bicosoecids [10,11]; a plastid-containing group, mostly phototrophic Ochrophyta $[13,14]$, that also includes known non-photosynthetic species such as apochlorotic nonphagotrophic diatoms from the genera Nitzschia [15,16] and Pseudonitzschia [15]; and phagotrophic chrysophytes, e.g., Mallomonas annulate 
and Spumella sp. $[17,18]$, to name a few. Interestingly, the ochrophytes also retain their plastids when they lose their autotrophic lifestyle [19], while convincing evidence for the presence of a plastid has not been reported for any of the other groups of stramenopiles, which are all non-photosynthetic. Their plastids are complex in origin, and are derived from a rhodophyte ancestor $[20,21]$. There is quite some debate on the relationship between the different groups of algae in which complex plastids are found (cryptophytes, haptophytes, ochrophytes, and most of the plastid-containing alveolates), as well as on the number and sequence of plastid gains, and losses or transfers between these groups [22-24]. Comparisons of the phylogenetic signal found in mitochondrial ( $\mathrm{mt})$, plastid, and nuclear genomes, as well as genome/transcriptome-wide targeting predictions, provide insights into this currently unresolved convolute $[23,25]$. However, these analyses need to be based on representative sets of organisms, covering the true diversity of these phyla. Phylogenomic analyses support the monophyly of the ochrophytes, while the non-photosynthetic stramenopiles consist of Oomycota (which. together with Ochrophyta, form the Gyrista), and Bigyra, a monophyletic group containing all other known heterotrophic stramenopiles [26]. While there are considerable genome sequence data and knowledge on the economically significant Oomycota [27], the other heterotrophic/bacterivorous stramenopiles, e.g., Platysulcus, Pirsonia and representatives of the MAST-3 clade, are underrepresented in sequence databases and in terms of knowledge about their ecology and physiology, in contrast to their global abundance in aquatic ecosystems [28,29]. Furthermore, Oomycota, due to their mainly saprophytic and parasitic life strategies, and due to their phylogenetic position as part of the Gyrista, should not be considered as the "true" representatives of heterotrophic stramenopiles, especially because many groups in the Bigyra, like species from Platysulcus [30], predatoric species of Developayella/Develorapax [31], and the MAST-4 [32] clade, seem to be exclusively composed of bacteriovorous lineages.

Bicosoecids are heterotrophic flagellates that represent a basal lineage of heterokonts $[5,13]$. Although this group has been assigned to unicellular photosynthetic stramenopiles due to their ultrastructure [33,34], analyses of molecular data have proven that Bicosoecida (clade Bikosea) are closer to stem stramenopiles [35]. Moreover, Bikosea were assigned to the group Bigyra with Blastocystis and Placidozoa as the closely related taxa [26]. The main ultrastructural character distinguishing bicosoecids from other stramenopiles is the architecture of the feeding basket/flagellar apparatus, which was first thoroughly examined in Cafeteria roenbergensis and has been established as an identifying feature since that time [30]. Nevertheless, the feeding basket/flagellar apparatus is an ancestral motif, conserved in two different forms in bicosoecids and chromulinalean chrysophytes, but lost in other stramenopiles [35], which lack the flagellar apparatus consisting of microtubular structures. The microtubular root (R3) has not been observed in any other stramenopiles in the sense of forming a prominent loop around the cell and hence it represents the main ultrastructural feature of Bicosoecida.

Due to the limited availability of sequence data from known species, molecular phylogenies are mostly restricted to a small ribosomal subunit of the nuclear RNAs (18S). The $18 \mathrm{~S}$ rDNA sequences in combination with the feeding basked morphology are suitable as a basis for initial species recognition (see $[5,36,37])$. To increase the sampling of heterotrophic stramenopiles, we isolated and cultivated a bicosoecid-like nanoflagellate from rock surface material collected in Norway. To determine its phylogenetic position more precisely, we studied the ultrastructure of this isolate and sequenced its mt genome.

\section{Material and Methods}

\subsection{Culture Conditions}

Cafileria marina was sampled as part of a rock surface mat community at a $3 \mathrm{~m}$ depth off the shore in Gaustad, Norway (Kvernesfjorden fjord, 62 59'07.9"N $7^{\circ} 19^{\prime} 17.4^{\prime \prime} \mathrm{E}$ ). Monoeukaryotic cultures were isolated by dilution and grown in Tissue Culture Flasks with ventilation screw caps in which the bottom was covered with $5-10 \mathrm{~mm}$ of liquid $\mathrm{f} / 2$ medium [38-40], with a salt concentration of $33.3 \mathrm{~g} / \mathrm{L}$ (Reef salt, Sera, Germany). The following antibiotics were used to clear the culture from 
ciliates and bacteria in this order: tetracyclin $10 \mu \mathrm{g} / \mathrm{mL}$; zeocin $10 \mu \mathrm{g} / \mathrm{mL}$; and ciprofloxacin $5 \mu \mathrm{g} / \mathrm{mL}$. Cultures were subcultured into the new media with antibiotic every second week. For accelerated growth during culture isolation, the $\mathrm{f} / 2$ media were supplemented with Tryptone Soy Broth (TSB) (Oxoid, Thermo-Fisher, Kansas City, KS, USA) ( $0.2 \mathrm{~g} / \mathrm{L}$ ) and sodium acetate (SA) ( $2.3 \mathrm{~g} / \mathrm{L})$. Media were calibrated to $\mathrm{pH}$ 7.9-8.3. Culture flasks with $\mathrm{C}$. marina were kept in the dark at $13-16{ }^{\circ} \mathrm{C}$; medium in the culture flasks was changed weekly and fresh cultures were inoculated at bimonthly intervals.

\subsection{Light and Scanning Electron Microscopy}

Light microscopic images were obtained using an Olympus BX53F microscope with Nomarski phase contrast equipped with a cooled digital camera DP72. The cell size measurements were performed using the Sens Standard Image Analysis Software V1.4. (Olympus, Japan). For scanning electron microscopy (SEM), cells were prepared using previously published protocol [41]. In brief, cells were chemically fixed $\left(2.5 \%\right.$ glutaraldehyde in $\mathrm{f} / 2$ medium, overnight at $\left.4{ }^{\circ} \mathrm{C}\right)$ and then rinsed with $\mathrm{f} / 2$ medium, and the cell suspension was placed on poly-L-lysine coated coverslips. Post-fixation was performed using $1 \% \mathrm{OsO}_{4}$ for $2 \mathrm{~h}$ at room temperature. After washing in $\mathrm{f} / 2$ medium, specimens were dehydrated with a graded series of acetone $(30 \%-100 \%)$ for $15 \mathrm{~min}$ at each step, critical point dried (CPD2 by Pelco, Fresno, CA, USA), and gold coated using a sputter coater Baltec SCD 050. The samples were examined by FE-SEM JSM 7401-F (JEOL.; Tokyo, Japan) at an accelerating voltage of $3 \mathrm{kV}$ using the GB-low mode.

\subsection{Transmission Electron Microscopy}

Cells were centrifuged (3000 rpm) for $10 \mathrm{~min}$, and the compact pellet was directly loaded into high-pressure freezing (HPF) specimen carriers (1.2 mm in diameter, Leica, Vienna, Austria) or optionally immersed in $20 \%$ bovine serum albumin/f/2 medium for $30 \mathrm{~min}$ before freezing. Specimens were frozen using a high-pressure freezer (EM Pact, Leica, Germany) and placed in freeze substitution medium containing $2 \% \mathrm{OsO}_{4}$ in $100 \%$ acetone pre-cooled to $-90^{\circ} \mathrm{C}$. Freeze substitution was performed following the protocol described previously [41]. Specimens were rinsed three times with water-free acetone and gradually infiltrated with 25\%,50\%, and 75\% low-viscosity Spurr resin (SPI Supplies, West Chester, PA, USA) in acetone for $3 \mathrm{~h}$ at each step. Cells partially released from the HPF carriers were placed in microtubes. Tubes were submersed in a container filled with $2 \mathrm{~L}$ of water, and the specimens were irradiated in a microwave oven for $30 \mathrm{~s}$ at $80 \mathrm{~W}$ three times at each resin infiltration step. After overnight incubation in $100 \%$ Spurr, the material was embedded in fresh resin and polymerized at $60{ }^{\circ} \mathrm{C}$ for $48 \mathrm{~h}$. Ultrathin sections were cut using an ultramicrotome (UCT.; Leica), collected on formwar-coated grids, contrasted in ethanolic uranyl acetate and lead citrate, and observed with a JEOL 1010 TEM (JEOL) at an acceleration voltage of $80 \mathrm{kV}$. Images were captured using a Mega View III camera (SIS.; Germany).

\subsection{Confocal Microscopy}

Two fluorescent dyes with a different affinity to color nuclear DNA (Hoechst 33342, Thermo-Fisher) and mitochondrial membranes (MitoTracker Orange CM-H2TMRos, Thermo-Fisher) were chosen to stain live cells. One to two milliliters of cultured cells were gently spun for $10 \mathrm{~min}$ at $5000 \mathrm{rcf}$; the supernatant was removed and replaced by isotonic sea salt solution $(33.3 \mathrm{~g} / \mathrm{L})$. Both dyes were added into the sea salt solution at a concentration of 1:1000, and tubes were placed in the dark for $30 \mathrm{~min}$. Slides for the confocal microscopy were prepared by placing stained cells on Superfrost Plus slides (Thermo-Fisher) to allow them to adhere to the slide surface. Excess dye was washed out by the sea salt solution to avoid cell disruption due to osmotic stress. Slides were then submerged in $4 \%$ paraformaldehyde (Sigma) for $30 \mathrm{~min}$, using the sea salt solution to dissolve the paraformaldehyde. After fixing cells in paraformaldehyde, slides were washed in the sea salt solution for $10 \mathrm{~min}$ and mounted by ProLong Gold antifade reagent (Thermo-Fisher). Slides were observed using the Olympus FluoView FV1000 confocal microscope equipped with a multi-line argon laser and a mercury arc lamp. 
Fluorescence was visualized upon exposure of the slides to filtered light. For Hoechst 33342, we used excitation at $405 \mathrm{~nm}$ and emission was filtered using a dichroic mirror SDM560 and a barrier filter of $425-475 \mathrm{~nm}$; for MitoTracker Orange CM-H2TMRos, we used excitation at $559 \mathrm{~nm}$, and emission was filtered with SDM640 and a barrier filter of $575-620 \mathrm{~nm}$. Fourteen layers at $0.35 \mu \mathrm{m}$ per slice were collected for each Z stack, which is the optimal value for the objective lens (100X) used. Obtained images were further analyzed by the real-time interactive data visualization software IMARIS Scientific 3D/4D x64 6.2.1 (Bitplane, Belfast, UK) to create the 3D models of stained organelles.

\subsection{DNA Isolation and $r D N A P C R$}

Genomic DNA was isolated using the DNeasy Tissue kit (Qiagen), following the manufacturer's instructions; DNA was quantified using a NanoDrop 1000 spectrophotometer (Thermo-Fisher). Ribosomal DNA was amplified using the AccuPrime high-fidelity Taq polymerase (Thermo-Fisher) with primers eurib_F (5'-AACCTGG TTGATCCTGCCAGT-3') and eurib_R (5'-TGATCCTTCTG CAGGTTCACCTAC-3') [42]. The cycling conditions of the PCR were as follows: 2 min at $94{ }^{\circ} \mathrm{C}$; ; and $30 \times\left[20 \mathrm{~s}\right.$ at $94{ }^{\circ} \mathrm{C}$.; $20 \mathrm{~s}$ at $61{ }^{\circ} \mathrm{C}$; $2 \mathrm{~min}$ at $\left.68^{\circ} \mathrm{C}\right]$. Amplicons were verified on $1 \%$ agarose gel stained by GelRed (Biotium, Hayward, CA, USA) and cloned into the pGEM-T Easy vector (Promega, USA). Plasmids from randomly chosen colonies were purified and sequenced using M13 primers by GATC Biotech (Konstanz, Germany). Eight variant sequences of C. marina were obtained. Preparation of the genomic DNA library was carried out by the commercial company Macrogen (Seoul, Korea), as well as all the post DNA isolation steps.

\subsection{Mitochondrial Genome Assembly and Analysis}

Raw reads were quality- and adapter-trimmed using trimmomatic v0.36 [43]. Bacterial reads were removed by the BlobTools workflow [44] searched against the NCBI RefSeq database (accessed April 6, 2018). Reads were assembled using SPAdes v3.11.1 [45]. The completeness of the assembly was assessed by searching for conserved eukaryotic single-copy orthologs with BUSCO2 [46]. The mitochondrial genome contig was identified by the similarity with the $C$. roenbergensis mt DNA (GenBank: AF193903) and annotated using MFannot (http://megasun.bch.umontreal.ca/cgi-bin/mfannot/mfannotInterface.pl, last accessed 18-05-2018), and tRNA genes were predicted by tRNAscan-SE v2.0.0 [47], followed by manual curation. Furthermore, predicted gene borders and annotations were individually checked using BLAST against the NCBI database. AUG and alternative triplets known to serve as $m$ t initiation codons (AUA in nad7 and AUU in rpl5 [48]) were considered as the starting points of translation, and only tRNAs on the transcribed strand were kept. Similarly, all other stramenopile mt genomes listed in Supplementary Tables S1 and S2 used for comparison were re-annotated with the up-to-date database of MFannot to allow a comparison of the gene content. No systematic improvement of annotation was attempted in these sequences. The circular map of the C. marina mt genome was generated with OGDRAW [49].

\subsection{Phylogenetic Analyses}

The obtained sequences were compared by a BLAST search with those available from the NCBI database to find the closest related taxa. Sequences of $C$. marina were manually inspected for errors and assembled using Geneious v11.1.4 [50]. Sequences of known bicosoecids and other stramenopiles were added to the final dataset, with apicomplexans and chlorophytes used as an outgroup. Sequences were aligned in the software MAFFT [51] with the default settings; the final alignment (1609 bp) was edited in Geneious v11.1.4. The best model of nucleotide substitution was chosen using jModelTest-2.1.4 [52]. Phylogenetic analyses were run under Bayesian Inference (BI) in the software MrBayes-3.2.6. [53]. BI runs were performed for 5 million generations, with four chains and four independent runs under the GTR+G+I model of molecular evolution. The coherence of each run was checked in TRACER v1.5 [54], and the estimated burn-in was 450,000 runs. The Maximum Likelihood (ML) tree was generated by the software PHYML [55], with the reliability of branching patterns within trees determined with 
1000 resampling steps using the bootstrap method. The final tree containing both types of support (posterior probability and bootstrap) was visualized and edited in FigTree v1.4.3. [56].

\section{Results}

\subsection{Cultivation}

C. marina was isolated from a mixed environmental sample of algae living on the surface of a rock collected in Kvernesfjorden bay, Norway (see Material and Methods), in which nanoflagellates were observed in the mucilage created by a pelagophyte alga (which we were not able to identify to a species level). The flagellate was extracted by placing culture into the darkness to eradicate the alga; the remaining ciliates and dinoflagellates were removed from the culture by using a variety of low-dose antibiotics and by culture dilution to get monoclonal colonies. F/2 medium was initially supplemented with TSB and SA.; which allowed the growth of various bacteria in the isolate. After some rounds of sub-culturing, the bacterial community was phenotypically homogenous, consisting only of bacteria identified by its 16S rDNA sequences as Sphingopyxis litoris strain Th8 (KC756877). These co-isolated bacteria were kept in co-cultures with C. marina as its food source.

\subsection{Cell Morphology}

The orientation of the cell was determined by the swimming direction being forward. Cells of $C$. marina have a rounded shape on the right side of the cell and a flat shape on the left side, resembling the shape of a capital " $\mathrm{D}$ "; the flagellae sub-apically emerge from a dent on the ventral side. The nanoflagellate is 3-4 $\mu \mathrm{m}$ wide and 5-6 $\mu \mathrm{m}$ long; the surface of the whole cell is smooth without any structural features that are visible by light or scanning electron microscopy (Figure 1a,b). C. marina has smooth anterior and posterior flagellae of equal length, approximately 1.5-2 times the length of the body. C. marina exhibits a tumbling movement. The anterior flagellum is free and sweeping, while the posterior one is used as an anchor and is attached to the surface. C. marina is a constant feeder, with the cytostome permanently formed. Spores or resting stages were never observed during our work with the organism.

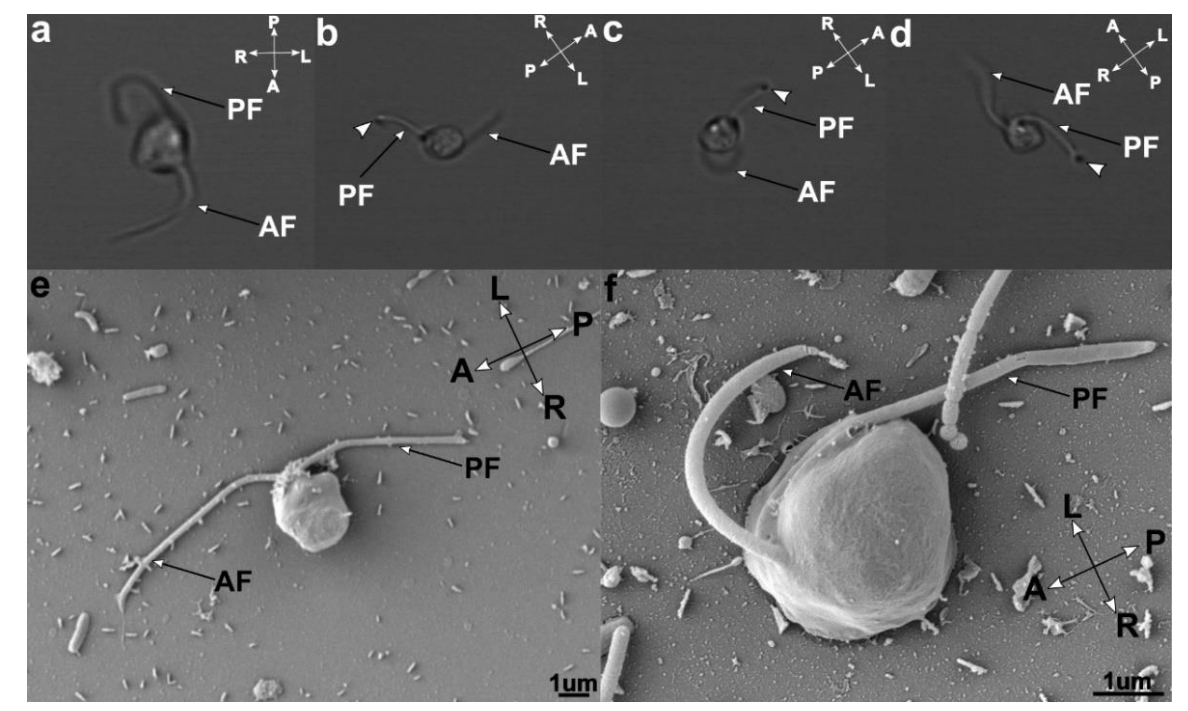

Figure 1. Cell appearance as observed using light microscopy (a,b,c,d) and scanning electron microscopy (SEM) (e,f). Light microscopy pictures show the attachment of the posterior flagellae (PF) to the surface (arrow) and the movement of the anterior flagellum (AF). SEM pictures (e,f) of Cafileria marina capturing the smooth surface of the cell wall and flagellae positions. The cell orientation was established arbitrarily by declaring the swimming direction to be forward and as follows: A: anterior, P: posterior, L: left, and R: right. 


\subsection{Ultrastructure}

The nucleus and mitochondria localize in the anterior part of the cell (Figure 2). The nucleus has a slightly elongated ovoid shape. The shape of the mitochondria varies from rod-shaped to horseshoe-shaped, and they are always found in close proximity to the nucleus (Figure 2). In young cultures (two weeks and younger), "junctions" are visible between the nucleus and mitochondria, where the mitochondrial and nuclear membranes appear partially dissolved and retreated to create an electron-dense disc between these compartments (Figure 2a-e). This phenomenon was observed during the early life stage of the flagellate. The mitochondrial cristae are tubular (Figure 2e,f), like in other stramenopile mitochondria. The Golgi is situated in the anterior part of the cell, with the cisternae aligning parallel to the nuclear surface. The number of cisternae varies between four and five (Figure 3). The shape of the Golgi apparatus changes from flat-stacked (Figure 3a,b) to rounded cisternae (Figure 3c,d), most likely depending on metabolic demands and the phase of the cell cycle [57,58]. In a more detailed view, the flat cisternae were seen to be curving inside and in some cases, created hollowed rounded shapes. Numerous small vesicles were scattered in the cytosol, while food vacuoles were placed in the posterior part and were considerably larger, taking up almost one third of the cell volume. Some of the food vacuoles contained intact or partially digested bacteria, which corroborates that C. marina is bacterivorous.

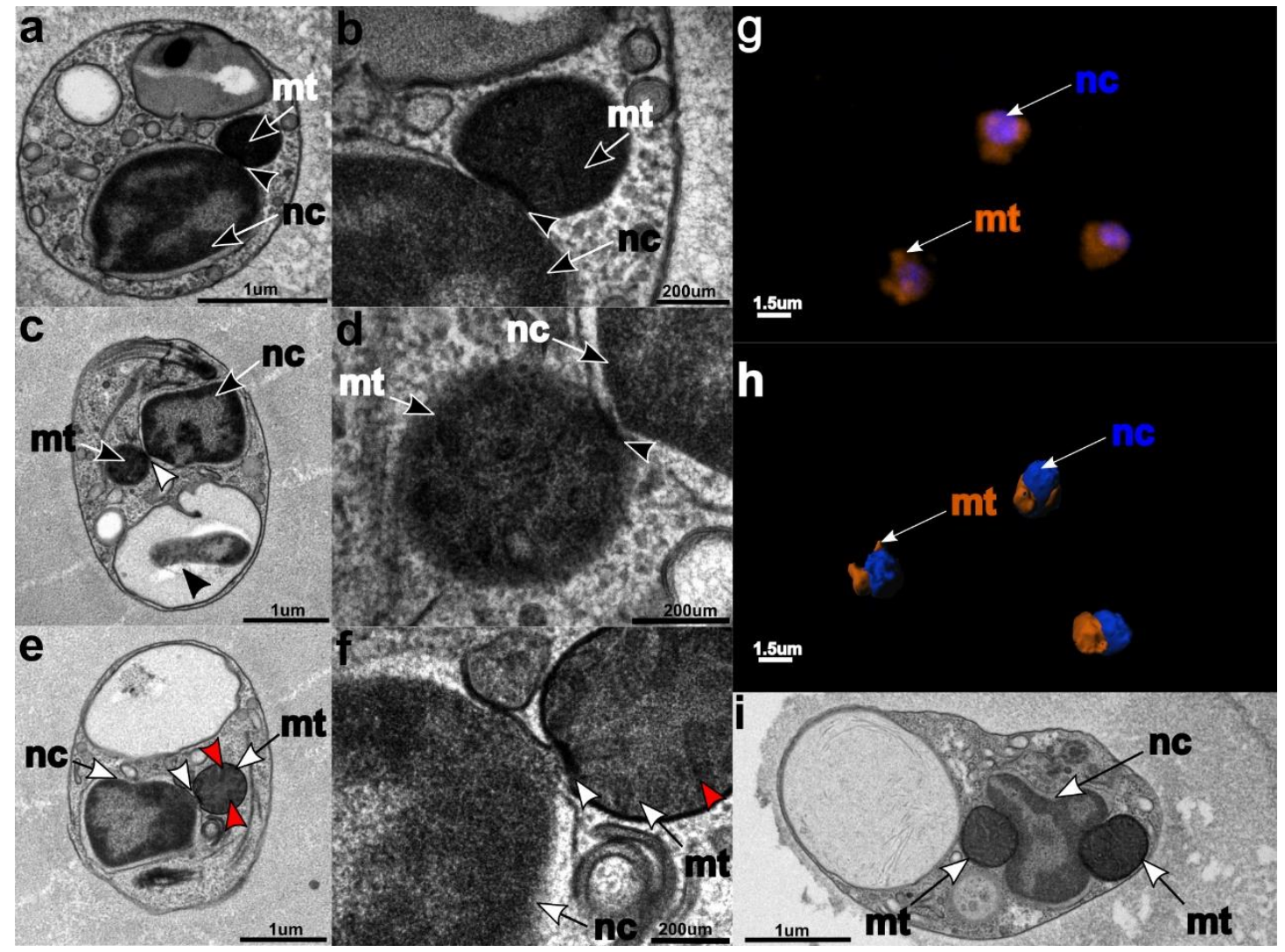

Figure 2. Connections between the nucleus (nc) and the mitochondria $(\mathrm{mt})$ were documented several times independently (white arrows) $(\mathbf{a}, \mathbf{b}, \mathbf{c}, \mathbf{d}, \mathbf{e}, \mathbf{f})$. The bicosoecids' $\mathrm{mt}$ has tubular cristae (e,f: red arrows). The connection of organelles was also observed using fluorescent staining of nc and mt and using confocal microscopy (g). Confocal Z-stacks were transformed into the 3D model (h) and $\mathrm{mt}$ appear in a location close to the nc. Mt can vary in shape and size, ranging from a simple spherical shape to a horseshoe shape, which is usually "hugging/wrapping" the whole nc (i). In the panel (c), devoured bacteria are visible in the food vacuole (black arrow). 


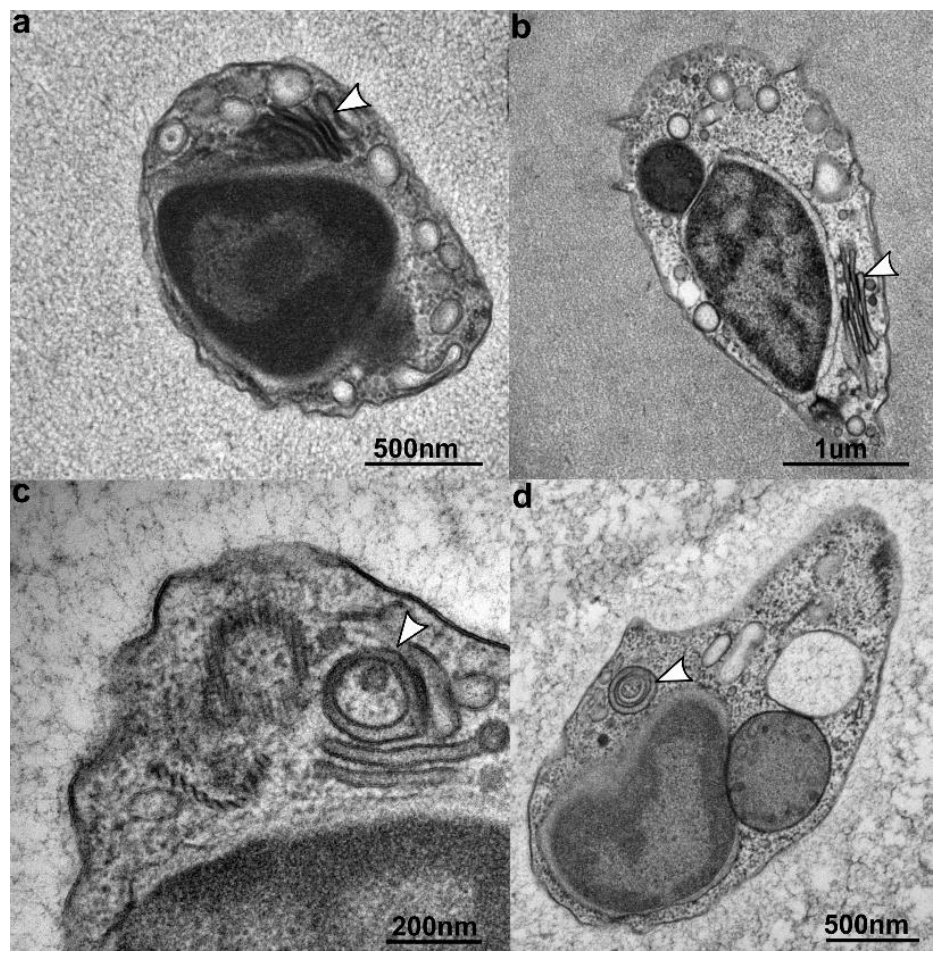

Figure 3. The Golgi apparatus changes shape during the cell cycle (arrow). The Golgi progressively changes from flat-shaped cisternae $(\mathbf{a}, \mathbf{b})$ stacked on top of each other to a rounded, circular, almost dish-like, shape (c,d).

\subsection{Flagellar Apparatus}

The flagellar apparatus of $C$. marina was inspected from different angles using TEM cross sections (Figure 4). Basal bodies (anterior basal body: AB.; posterior basal body: PB) were situated in the anterior region of the cell, usually arranged at an acute $\left(45^{\circ}\right)$ angle to each other (Figure $\left.4 a\right)$. Both basal bodies were connected with one striated fiber extended between their proximal ends. Each flagellum consisted of a $9+2$ axoneme, and both flagellae lacked any paraxial inclusions or flagellar hairs (Figure 1). The flagellae (anterior flagellum: AF.; posterior flagellum: PF) were connected to the corresponding basal body via a concave transition plate, from which the two inner axonemes appeared to grow. The basal bodies were placed in the anterior part of the cell and connected with electron-dense fibers (Figure 4a,b: BC). Four roots (R1-4) and additional tubular structures were discovered in the TEM pictures. Because R3 consists of eight microtubules and passes along the anterior part of the cell, it is also the most visible and distinctive character of the flagellar apparatus. Root R3 starts under the proximal ends of PB. Tubules follow the perimeter of the cell in the anterior part, and the whole structure forms a loop around the cytostome. An additional tubular structure, rootlet R2, has three microtubules horizontally positioned next to each other and at right angles to both PB and R3. Therefore, the R2 and R3 tubules are arranged in an 'L' shape near the proximal end of PB.; where both sets nucleate. The R2 rootlet goes alongside the frontal part of the cell, initially copying the direction of R3 tubules, but then R2 splits and follows the cell membrane further down to the caudal end. The remaining roots (R1 and R4) all consist of single microtubules; R1 starts close to the distal end of PB and passes towards the left side of the cell. Similar to the R1 root, R4 follows the same direction, but starts at the distal end of $A B$. The last microtubular structure ' $x$ ' starts close to the right distal ends of both flagella and moves down along the right side of the cell. 


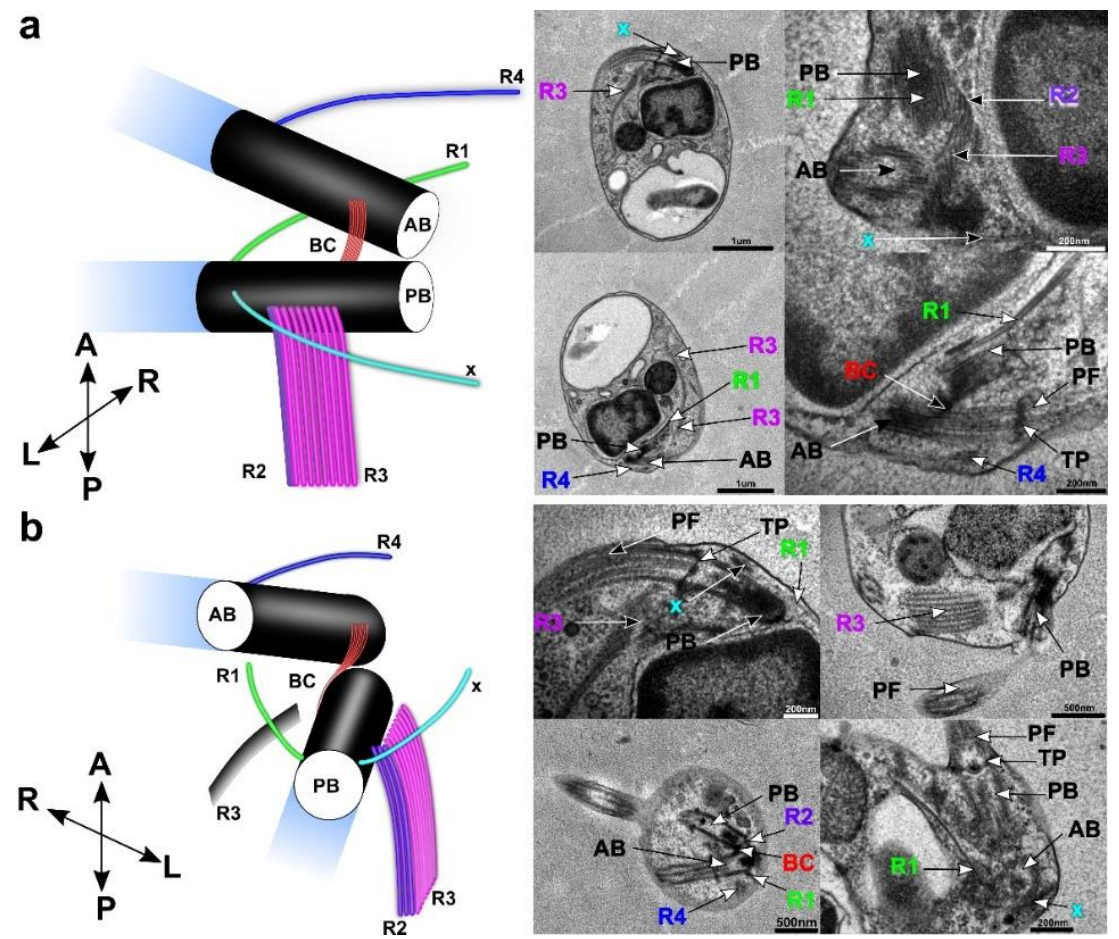

Figure 4. The flagellar apparatus (FA) was reconstructed based on TEM pictures; 3D models of the side view (a) and front view (b) were created. Pictures corresponding to the different view angles were added with morphological structures marked in the pictures. The whole FA comprised of the anterior and posterior basal body (AB and PB.; respectively), the connection between basal bodies (BC), four microtubular roots (R1-R4), and the multi-microtubular structure "abc". In TEM pictures, transition plates (TP) of the anterior and the posterior flagella (AF and BF.; respectively) can also be seen. The cell orientation is shown in the left corner of the drawing: A: anterior, P: posterior, L: left, and R: right. Microtubular roots R1-R4 are the main structures forming the FA and supporting the feeding basket of C. marina; the R3 root is the defining morphological structure for Bicosoecida and consists of eight microtubules; the R2 root consists of three microtubules; and the remaining roots R1, R4, and ' $x$ ' consist of one microtubule. The number and angle of microtubules of the each root and their presence/absence are species-specific, so these structures are utilized as species-determining features.

\subsection{Phylogenetic Analysis}

Our $18 \mathrm{~S}$ sequential data were joined with sequences from other bicosoecids found at NCBI GenBank $^{\mathrm{TM}}$ and apicomplexans used as an outgroup. We obtained eight rDNA sequences $(7 \mathrm{amplicons}$ $1753 \mathrm{bp}$, one partial sequence) from a mono-eukaryotic culture of C. marina, which were deposited in GenBank ${ }^{\mathrm{TM}}$ under accession numbers MK704414-21. Both analyses provided very similar results, so only one BI tree is presented with posterior probabilities (PP) and bootstrap branch supports (Figure 5 and Figure S1). All these sequences clustered within the bicosoecid clade and formed an isolated group with Caecitellus parvulus as the closest related taxon (Figure 5). The rDNA sequences of $C$. marina differ by, at most, 13 bp ( $0.74 \%$ difference), where some alterations might have been caused by amplification or sequencing errors. The average difference between $C$. marina and Caecitellus rDNA sequences is $17.19 \%$, well exceeding the intra-genus variability of Caecitellus rDNA sequences (7.19\% difference). Interestingly, the sequence of Rictus lutensis clustered with Blastocystis sequences in both types of analyses (BI and ML); however, with a somewhat lower branch support in the former case, suggesting a long branch attraction artifact. Our analyses suggest that there is a diversity of undescribed bicosoecid sequences more distantly, but robustly, related to known species. C. marina and Halocafeteria rDNA sequences differ in a similar range (14.01\%). We consider these differences large enough to delimit a new genus named Cafileria. 


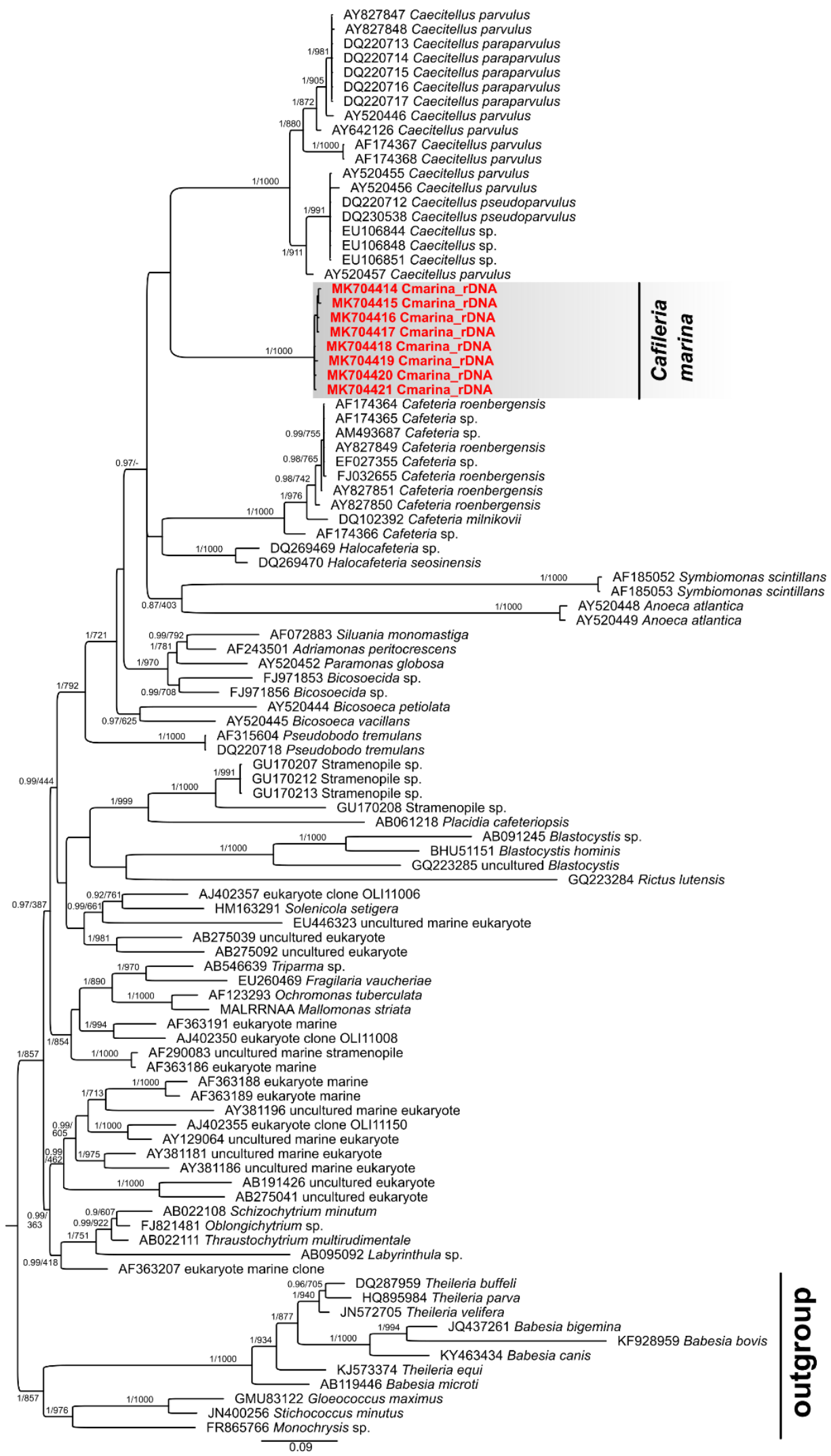

Figure 5. Phylogenetic tree based on $18 \mathrm{~S}$ sequences of bicosoecids and closely related representatives of Stramenopiles with the final length of alignment of $1609 \mathrm{bp}$. The presented tree was computed by the software MrBayes. Sequences of apicomplexans were used as an outgroup to root the final tree. Statistical support for each branch was obtained from the Bayesian posterior probability and maximum-likelihood bootstrap. Posterior probabilities lower than 0.86 are not shown in the figure. 


\subsection{Mitochondrial Genome}

The assembled reads yielded 1613 contigs, with the best blast hits among heterotrophic stramenopiles (oomycetes, Blastocystis, Cafeteria). Due to the low genome coverage of the assembly, as assessed using BUSCO2 [46], contigs other than the mt genome contigs were not analyzed in this study, with the exception of a screen for the possible presence of a plastid (due to the ongoing discussions about the distribution of plastids of red algal origin in different groups of algae, see introduction). None of the genome contigs had similarities to known plastid genomes. Furthermore, screening of the predicted proteome from the contigs with the plastid protein prediction tool AFAFind [59] (utilizing the tool SignalP 3.0 NN [60]) resulted in a very low number of proteins with positive prediction results, which can be explained by the false positive rate of ASAFind. Furthermore, during our cultivation and microscopy work with C. marina, we never observed a change in phenotype between cells cultured in the dark or in the light. We therefore think that $C$. marina does not have a plastid.

Among the contigs, NODE_11 showed overall similarity to mt genomes, most notably that of C. roenbergensis. The phylogenetic analysis placed cox 1 as the NODE_11 sister to C. roenbergensis (Figure S2). NODE_11 was therefore identified as the $\mathrm{mt}$ genome of $C$. marina. The, C. marina $\mathrm{mt}$ genome is circular-mapping and $42,797 \mathrm{bp}$ long, with a GC content of $21.3 \%$. While the size and the gene content are similar to other heterotrophic stramenopile $\mathrm{mt}$ genomes, the GC content is lower (Table S1), second only to the genome of the structurally-reduced mt-related organelle of Blastocystis (Table S2). The single $r n s$ and $r n l$ genes for the $\mathrm{mt}$ rDNA are organized in tandem. The genome of C. marina encodes tRNAs cognate for most amino acids, except for Thr, Ala, and Gly (Figure S2). These tRNAs are frequently present in the mt proteins ( $4.8 \%$ for Ala, $6.4 \%$ for Gly, and $5.9 \%$ for Thr). A suppressor tRNA cognate to the UGA stop codon is also present.

The genetic code is of type 4, with UGA coding for Trp and UAA/UAG serving as translational stops. In most cases, AUG is the initiation codon, but AUA and AUU are putatively used in nad7 and $r p l 5$, respectively. Protein-coding genes encode subunits of the respiratory complexes I.; III.; and IV.; and ATP synthase, and subunits of the ribosomal LSU and SSU. Except for the C. marina rpl5, the gene set is conserved in the two bicosoecids. The, C. marina nad11 gene has a 426-bp extension at its 3 '-end (compared to Cafeteria) that encodes a molybdopterin oxidoreductase $4 \mathrm{Fe}-4 \mathrm{~S}$ domain. In most stramenopiles (but not in Chrysophyceae and Oomycetes), nad11 is split into two independently translated ORFs [61]. C. marina is so far the only species known to encode the $4 \mathrm{Fe}-4 \mathrm{~S}$ domain with the $\mathrm{N}$-terminal ferredoxin-type NADH/ubiquinone oxidoreductase module rather than the C-terminal molybdopterin domains, adding to the list of evolutionary splits of nad11 in stramenopiles [61]. The functional consequences of this modular arrangement of NAD11 are unclear. In addition to annotateable $\mathrm{mt}$ genes in C. marina, six hypothetical ORFs have no orthologs retrieved by a BLAST search, while the mt genome of Cafeteria shows four such regions. We could not find any group I or group II introns in the mt genome. Despite the quite conserved gene content in the mitochondria of bicosoecids, their order is highly rearranged in C. marina when compared to Cafeteria (Figure S2) and other heterotrophic stramenopiles (Figure 6). Alignment of C. marina and C. roenbergensis $\mathrm{mt}$ genomes revealed seven regions of higher similarity, most of which were limited to single genes. Only two gene clusters appear to share the same order in the two species (atp8-atp1-atp6 and nad5-rps13-rpl2-rps19). Due to the scarce sampling of heterotrophic stramenopile mt genomes, it is not possible to decide which of the species is closer to the ancestral gene architecture. 
a

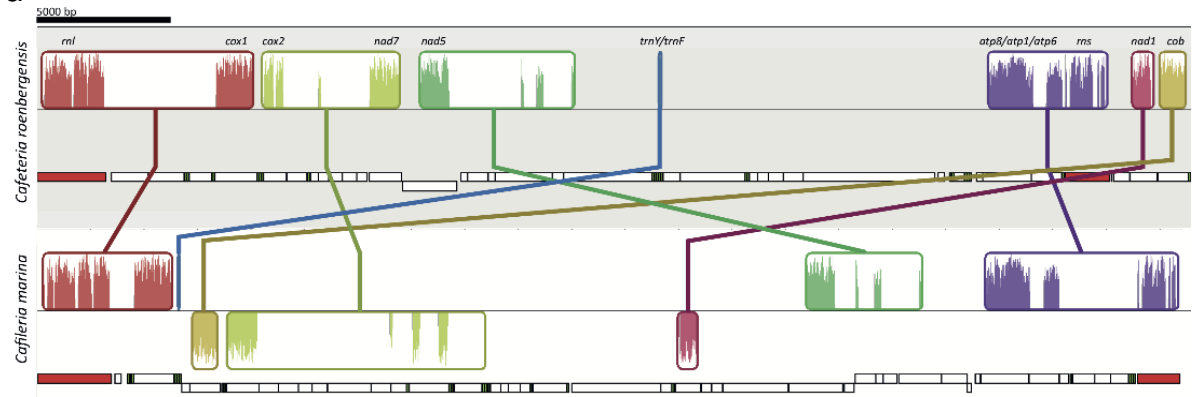

b

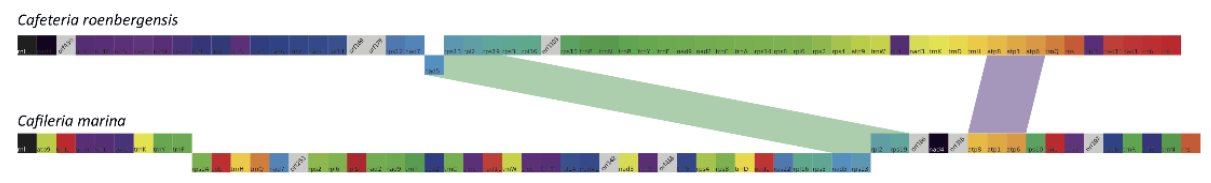

Figure 6. Collinearity of bicosoecid mitochondrial genomes. Panel (a) Very low level of collinearity on the genomic scale (as determined by Mauve) was observed among Cafeteria roenbergensis and Cafileria marina. Genes encoded by the plus and minus strand are depicted above or below the line representing the mitochondrial genomic sequence. Ribosomal, tRNA.; and protein-coding genes are schematically shown in red, green, and white, respectively. Gene-level collinearity Panel (b) is also very low, corroborating the numerous genomic rearrangements seen on the genomic level.

\section{Discussion}

We conducted a thorough morphological, ultrastructural, and molecular examination of the novel marine heterotrophic nanoflagellate C. marina. It feeds on bacteria phagotrophically and belongs to the bicosoecids. Morphological and ultrastructural features typically described for bicosoecid cells - two flagella, the flagellar apparatus, microtubular root R3, and the tubular cristae in mitochondria $[7,35,36]$-were observed in C. marina. The bicosoecid lives and glides through the mucilage produced by a pelagophyte alga, with which it is in close association. A characteristic gliding/tumbling movement, with the anterior flagellum free and sweeping, while the posterior one was used as an anchor attached to the surface, was observed during cultivation. This type of movement has also been described for other bacteria-ingesting bicosoecids [62,63]. According to our observations, C. marina is a permanent feeder. Although the cytostome has not been seen in EM pictures, we assume that it is permanently present; firstly, due to the presence of the bacteria in the food vacuole (Figure $2 \mathrm{c}$ black arrow), and secondly, due to the similarity of the life style (bacteriovory in marine sediments?) of Caecitellus paroulus [64] and Rictus lutensis [5], which are two related bicosoecids with cytostomes. This supposition is corroborated by the presence of $\mathrm{R} 3$ and ' $\mathrm{x}$ ', which are structures typically associated with support of the feeding lip and the starting point of the cytostome [37]. Available studies of bicosoecids have shown that they have four microtubular roots $[37,65,66]$. For the description of ultrastructural characters, we used previously established terminology [37]. The flagellar apparatus of C. marina is similar to C. parvulus and R. lutensis [5]; however, some tubular features are different/missing. The same ultrastructural characters of the flagellar apparatus are found in C. marina, C. parvulus, R. lutensis, and $C$. roenbergensis; however, the number of microtubules for roots differs from the above named species. The most visible difference is in the R3 root: $C$. parvulus has $\sim 8-24$ microtubules; $R$. lutensis has $\sim 4-50$ microtubules; and C. roenbergensis and C. marina have 8 microtubules. Some of the species also exhibit other unique features, e.g., $R$. lutensis has two additional microtubular structures ' $x$ ' and ' $\mathrm{S}$ ', both of which are single-microtubule structures, whilst $C$. roenbergensis is so far the only species with secondary cytoskeletal microtubules on the R4 root (see Table 1 for details). The number of microtubules per root is thus unique in C. marina. 
Table 1. Comparison of the Cafileria marina flagellar apparatus with closely related bicosoecids. The terminology was adopted from [30]. 'S' is the additional microtubular structure unique to $R$. lutensis, similar to ' $\mathrm{x}$ ', which consists of a single microtubule, but lays on top of the R3 root and copies its shape.

\begin{tabular}{|c|c|c|c|c|c|c|c|c|c|c|c|c|c|}
\hline \multirow[t]{2}{*}{$\begin{array}{l}\text { Ultrastructure of the } \\
\text { Flagellar Apparatus }\end{array}$} & \multicolumn{3}{|c|}{ R1 } & \multicolumn{3}{|c|}{$\mathbf{R} 2$} & \multicolumn{3}{|c|}{ R3 } & \multicolumn{3}{|c|}{$\mathrm{R} 4$} & \multirow{2}{*}{$\begin{array}{l}\text { Additional } \\
\text { Microtubular } \\
\text { Structures }\end{array}$} \\
\hline & Present & $\begin{array}{l}\text { Number of } \\
\text { Microtubules }\end{array}$ & $\begin{array}{l}\text { Original } \\
\text { Name in the } \\
\text { Publication }\end{array}$ & Present & $\begin{array}{l}\text { Number of } \\
\text { Microtubules }\end{array}$ & $\begin{array}{l}\text { Original } \\
\text { Name in the } \\
\text { Publication }\end{array}$ & Present & $\begin{array}{l}\text { Number of } \\
\text { Microtubules }\end{array}$ & $\begin{array}{l}\text { Original } \\
\text { Name in the } \\
\text { Publication }\end{array}$ & Present & $\begin{array}{l}\text { Number of } \\
\text { Microtubules }\end{array}$ & $\begin{array}{l}\text { Original } \\
\text { Name in the } \\
\text { Publication }\end{array}$ & \\
\hline \multicolumn{14}{|l|}{$\begin{array}{l}\text { Species and } \\
\text { publication }\end{array}$} \\
\hline $\begin{array}{l}\text { Halocafeteria seosinensis } \\
\text { Park et al., } 2006 \text { [7] }\end{array}$ & & Not confirmed & & + & 8 & & & Not confirmed & & & Not confirmed & & \\
\hline Cafeteria roenbergensis & + & 2 & R4 & + & 3 & $a b c$ & + & 8 & & + & 2 & R1 & $\mathrm{x}$ \\
\hline $\begin{array}{l}\text { O'Kelly and Patterson } \\
1996[35]\end{array}$ & & & & & & & & & \multicolumn{5}{|c|}{ Secondary cytoskeletal microtubules } \\
\hline $\begin{array}{c}\text { Rictus lutensis } \\
\text { Yubuki et al., } 2010 \text { [5] }\end{array}$ & + & 2 & R4 & + & 3 & $a b c$ & + & $\sim 4-50$ & R2 & + & 2 & R3 & $\begin{array}{l}\mathrm{x} \\
\mathrm{S}\end{array}$ \\
\hline $\begin{array}{c}\text { Caecitellus paroulus } \\
\text { O'Kelly and Nerad } \\
1998 \text { [64] }\end{array}$ & + & 2 & R1 & + & 3 & $a b c$ & + & $\sim 8-24$ & R2 & + & 2 & R1 & $x$ \\
\hline Cafileria marina & + & 1 & & + & 3 & & + & 8 & & + & 1 & & $\mathrm{x}$ \\
\hline
\end{tabular}


A peculiar major ultrastructural phenomenon of $C$. marina is the tight connection of the mitochondria and nucleus in young cultures (Figure 2). Although the clustering of mitochondria near the nucleus was documented for young rat heart cells [67], endothelial cells of pulmonary arteries in mammalian cells [68], mitochondria located in neurons [69], and in thymocytes and leukemia cell lines [70], a full conjunction of these two compartments, as seen in Figure 2, has not yet been described. This organellar conjunction might be parallel to the known tethering and synergy between the mitochondria and endoplasmic reticulum (ER) [71,72]. Their connection is involved in the regulation of lipid synthesis, $\mathrm{Ca}^{2+}$ signaling, and transport from ER to mitochondria [71-73]. The bonding between the two compartments directly affects the mitochondria biogenesis [74]. According to previous studies and results, we formed five hypotheses to explain this peculiarity: (i) The proximity of organelles might reflect intense ATP/ADP exchange between the mitochondria and the nucleus, via energy-dependent direct transport. The junction could serve as an energy "bridge" to cover the high energy demand of the nucleus during rapid cell growth and division [67,75]. A similar provision of energy has been described for multiple cell lines/types, e.g., cardiac cells [67] or endothelial cells of pulmonary arteries [68]; (ii) the connection might facilitate the direct transport of tRNAs that are not encoded by the mt genome, but are required for mitochondrial translation. This would be similar to the situation in Trypanosoma brucei, in which all mitochondrial tRNAs are encoded in the nucleus and are actively transported into the mitochondrion $[76,77]$. In the case of $C$. marina, alanine, glycine, and threonine (the amino acids carried by the exclusively nuclear-encoded tRNAs tRNA ${ }^{\text {Ala }}$, tRNA ${ }^{\text {Gly }}$, and $\left.\mathrm{tRNA}^{\mathrm{Thr}}\right)$ are quite abundant $(4.8 \%, 6.4 \%$, and $5.9 \%$ of the predicted proteome, respectively) in the mitochondria-encoded proteins, hence the corresponding tRNAs must be imported into the mitochondrion; (iii) we should also take into consideration the hypothetical direct export of mRNA from the nucleus to the mitochondria as a template for the mitochondrial protein translation. Transport of mRNAs encoding mitochondrial proteins to the mitochondrial membrane and their cytosolic transcription is, in principle, known, but some mechanisms and associated processes are still not fully understood and explained [78,79]. Regarding the mRNA transport hypothesis, it is interesting to know that the sharing of mRNA molecules between cells has been described for placental cells under oxidative stress in the syncytial tissue; mRNAs transcribed by active cells can then diffuse freely throughout the syncytioplasm into transcriptionally-inactive cells of the syncytium [80]. However, currently, there is no known molecular machinery that can specifically recognize and transport mRNAs; (iv) the observed junction could also represent a physical connection of mitochondria and the nucleus during cell division to mechanically ensure equal segregation into the daughter cells. These cellular-level changes in organelle organization might also be linked to the variety of mitochondrial shapes, or be a special case of "kiss-and-run" mitochondrial motility dynamics, similar to the ones described by [81]; (v) last but not least, the observed junctions might simply be a consequence of the small cell size and efficient intracellular organization. Because of the small cell size, the ER is extremely reduced in C. marina. Since the nuclear envelope is continuous with the ER.; the observed junctions might also represent mitochondria-associated membranes. These are contact sites between ER and mitochondrial membranes [82], that in the case of C. marina, might reside directly at the outer side of the nuclear envelope.

In addition to the nucleus-mitochondria connections, we observed changes in the shape of the C. marina Golgi apparatus during the cell cycle (Figure 3). Interestingly, different forms and arrangements of Golgi cisternae seem to correlate with different cell cycle stages. A similar phenomenon was predicted for mammalian cells $[58,83]$ and later observed in vivo [57]. While the flattening and curvature of the human Golgi has been associated with membrane curvature generators and changes in sphingomyelin metabolism [57], in the case of the described nanoflagellate, the mechanism remains elusive.

The performed phylogenetic and morphological analyses with the comparison to other studies showed that $C$. parvulus and the representatives of the family Cafeteriidae (Cafeteria sp. and Cafeteria mylnikovii) are the closest relatives to the novel bicosoecid species. Although the morphological features showed more 
similarities to C. roenbergensis, namely the microtubule number of individual roots, shown in Table 1, both types of molecular data ( $\mathrm{mt}$ genome and $18 \mathrm{~S}$ ) share more similarities with C. parvulus. The results of our phylogenetic analyses showed that $C$. marina is not only a newly discovered species, but its divergence also qualifies it for placement in a new genus. Moreover, the already mentioned paraphyly of the genus Cafeteria in [37] and [26] was confirmed by our analyses. However, this assumption is only based on the position of a single sequence of Pseudobodo tremulans in [37] and of Cafeteria sp. in [26], and further investigation is thus needed to confirm this claim.

Besides the $C$. roenbergensis $\mathrm{mt}$ genome, there is no other larger-scale bicosoecid data available for comparison. Our analyses showed a similar composition of the C. marina mt genome to the C. roenbergensis $\mathrm{mt}$ genome; however, with a different gene arrangement. The features typical for all stramenopiles, the lack of tRNA ${ }^{\mathrm{Thr}}$ and the presence of suppressor tRNA consanguineous to the UGA stop codon, were also found in the C. roenbergensis mt genome, but the lack of tRNA ${ }^{\text {Ala }}$ and tRNA Gly had been unique to C. marina up to now.

To summarize our findings, phylogenetic and morphological data concordantly place Cafileria marina into the family Bicosoecidae (Stein, 1878), with enough diverging evidence from known taxa to propose C. marina as a new species and genus of this family.

\subsection{Taxonomic Summary}

Cafileria marina is a heterotrophic stramenopile feeding on bacteria and is described under the International Code of Zoological Nomenclature.

\subsection{Cafileria n. gen.}

Flattened pyriform cells with two naked flagella, displaying tumbling movement with one flagellum attached to the substrate and the other flagellum moving. They have no lorica, cell wall, or other surface structures, and feed on bacteria by phagotrophy.

\subsection{Type species}

Cafileria marina n. sp.

\subsection{Type locality}

A three-meter depth off the shore in Gaustad, Norway (Kvernesfjorden fjord, $62^{\circ} 59^{\prime} 07.9^{\prime \prime} \mathrm{N}$ $\left.7^{\circ} 19^{\prime} 17.4^{\prime \prime} \mathrm{E}\right)$, was used in this study.

\subsection{Cafileria marina n. sp.}

\subsubsection{Description}

Cells 3-4 $\mu \mathrm{m}$ wide and 5-6 $\mu \mathrm{m}$ long, with anterior and posterior flagella of equal length that were 1.5-2 times length of the body, were employed. The cells and flagella had a smooth surface. The flagellar apparatus consisted of four roots (R1-R4) that did not have any secondary cytoskeletal microtubules.

\subsubsection{Etymology}

Cafileria marina is named after the "kafilerie", the Czech name of the place where the biomass of animal origin is dismantled and conditioned for the production of lipids, glue, and fertilizers. Therefore, we have seen a parallel with the feeding habits of the newly discovered nanoflagellate, which feasts on bacteria that recycle organic materials found in the biofilm mucillage that makes up their habitat. The species name marina stands for the marine origin of the species. 


\subsubsection{Hapantotype}

The designated hapantotype has been deposited as TEM and SEM specimens, and cryo-mixed cultures of nanoflagellate $C$. marina and bacteria S. litoris in the slide collection at the Biological Centre of the Czech Academy of Sciences, Institute of Parasitology, Ceske Budejovice, Czech Republic, under the accession number IP CAS Pro 59.

\subsubsection{Assignation}

Eukaryota; Stramenopila; Bicosoecida.

Supplementary Materials: Supplementary materials can be found at http://www.mdpi.com/2076-2607/7/8/240/s1.

Author Contributions: J.R. discovered and cultured the nanoflagellate. D.J. and Z.F. contributed by equal measure to the manuscript. D.J. performed phylogenetic analyses and confocal microscopy, obtained ultrastructural data, and drafted the manuscript. Z.F. conducted TEM and SEM; analysed the mitochondrial genome, and contributed to manuscript writing. A.G. and M.O. contributed to data interpretation and manuscript writing. All authors contributed to the final version of the manuscript.

Funding: This work was supported by the Czech Science Foundation [18-13458S] and the OPVVV project [CZ.02.1.01/0.0/0.0/16_019/0000759] (Centre for Research of Pathogenicity and Virulence of Parasites).

Acknowledgments: We acknowledge the core facility of the Institute of Parasitology, BC ASCR in České Budějovice, Czech Republic, supported by the MEYS CR (LM2015062 Czech-BioImaging). Computational resources were provided by the CESNET LM2015042 and the CERIT Scientific Cloud LM2015085, under the programme "Projects of Large Research, Development, and Innovations Infrastructures". The unpublished genomic sequence of Cafeteria roenbergensis was kindly provided by Matthias Fischer (Max Planck Institute for Medical Research, Heidelberg, Germany).

Conflicts of Interest: The authors declare no conflicts of interest. This publication has been registered with the ZooBank database (http://zoobank.org/) with the Life Science Identifier urn:lsid:zoobank.org:pub:01CC4CE94CAB-4ABC-B436-AC9C3DACCD0C, and the genus Cafileria and species name Cafileria marina have been deposited in Zoobank with the Life Science Identifiers urn:lsid:zoobank.org:act:2D366342-8B16-4F18-8D8EA8B3C81CD185 and urn:lsid:zoobank.org:act:51EC7CE9-3376-415F-9DB1-B68F198C3FB9, respectively.

\section{References}

1. Nakano, S.I.; Ishii, N.; Manage, P.M.; Kawabata, Z. Trophic roles of heterotrophic nanoflagellates and ciliates among planktonic organisms in a hypereutrophic pond. Aquat. Microb. Ecol. 1998, 16, 153-161. [CrossRef]

2. Sanders, R.W.; Porter, K.G.; Bennett, S.J.; Debiase, A.E. Seasonal patterns by flagellates, ciliates, rotifers, and cladocerans in a freshwater community cladocerans planktonic and. Limnol. Oceanogr. 1989, 34, $673-687$. [CrossRef]

3. Kopylov, A.I.; Kosolapov, D.B.; Romanenko, A.V.; Degermendzhy, A.G. Structure of planktonic microbial food web in a brackish stratified Siberian lake. Aquat. Ecol. 2002, 36, 179-204. [CrossRef]

4. Saccà, A.; Borrego, C.M.; Renda, R.; Triadó-Margarit, X.; Bruni, V.; Guglielmo, L. Predation impact of ciliated and flagellated protozoa during a summer bloom of brown sulfur bacteria in a meromictic coastal lake. FEMS Microbiol. Ecol. 2009, 70, 42-53. [CrossRef] [PubMed]

5. Yubuki, N.; Leander, B.S.; Silberman, J.D. Ultrastructure and molecular phylogenetic position of a novel phagotrophic stramenopile from low oxygen environments: Rictus lutensis gen. et sp. nov. (Bicosoecida, incertae sedis). Protist 2010, 161, 264-278. [CrossRef] [PubMed]

6. Scheckenbach, F.; Wylezich, C.; Weitere, M.; Hausmann, K.; Arndt, H. Molecular identity of strains of heterotrophic flagellates isolated from surface waters and deep-sea sediments of the South Atlantic based on SSU rDNA. Aquat. Microb. Ecol. 2005, 38, 239-247. [CrossRef]

7. Park, J.S.; Cho, B.C.; Simpson, A.G.B. Halocafeteria seosinensis gen. et sp. nov. (Bicosoecida), a halophilic bacterivorous nanoflagellate isolated from a solar saltern. Extremophiles 2006, 10, 493-504. [CrossRef] [PubMed]

8. Jones, R.I. Mixotrophy in planktonic protists: An overview. Freshw. Biol. 2000, 45, 219-226. [CrossRef]

9. Massana, R.; Terrado, R.; Forn, I.; Lovejoy, C.; Pedrós-Alió, C. Distribution and abundance of uncultured heterotrophic flagellates in the world oceans. Environ. Microbiol. 2006, 8, 1515-1522. [CrossRef]

10. Moriya, M.; Nakayama, T.; Inouye, I. Ultrastructure and $18 \mathrm{~S}$ rDNA sequence analysis of Wobblia lunata gen. et sp. nov., a new heterotrophic flagellate (Stramenopiles, Incertae sedis). Protist 2000, 151, 41-55. [CrossRef] 
11. Sekiguchi, H.; Moriya, M.; Nakayama, T.; Inouye, I. Vestigial chloroplasts in heterotrophic stramenopiles Pteridomonas danica and Ciliophrys infusionum (Dictyochophyceae). Protist 2002, 153, 157-167. [CrossRef] [PubMed]

12. Andersen, R.A. Biology and systematics of heterokont and haptophyte algae. Am. J. Bot. 2004, 91, 1508-1522. [CrossRef] [PubMed]

13. Cavalier-Smith, T.; Chao, E.E.-Y. Phylogeny and megasystematics of phagotrophic heterokonts (kingdom Chromista). J. Mol. Evol. 2006, 62, 388-420. [CrossRef] [PubMed]

14. Riisberg, I.; Orr, R.J.S.; Kluge, R.; Shalchian-Tabrizi, K.; Bowers, H.A.; Patil, V.; Edvardsen, B.; Jakobsen, K.S. Seven Gene Phylogeny of Heterokonts. Protist 2009, 160, 191-204. [CrossRef] [PubMed]

15. Kamikawa, R.; Moog, D.; Zauner, S.; Tanifuji, G.; Ishida, K.I.; Miyashita, H.; Mayama, S.; Hashimoto, T.; Maier, U.G.; Archibald, J.M.; et al. A non-photosynthetic diatom reveals early steps of reductive evolution in plastids. Mol. Biol. Evol. 2017, 34, 2355-2366. [CrossRef] [PubMed]

16. Kamikawa, R.; Azuma, T.; Ishii, K.I.; Matsuno, Y.; Miyashita, H. Diversity of organellar genomes in non-photosynthetic diatoms. Protist 2018, 169, 351-361. [CrossRef] [PubMed]

17. Olefeld, J.L.; Majda, S.; Albach, D.C.; Marks, S.; Boenigk, J. Genome size of chrysophytes varies with cell size and nutritional mode. Org. Divers Evol. 2018, 18, 163-173. [CrossRef]

18. Rottberger, J.; Gruber, A.; Boenigk, J.; Kroth, P.G. Influence of nutrients and light on autotrophic, mixotrophic and heterotrophic freshwater chrysophytes. Aquat. Microb. Ecol. 2013, 71, 179-191. [CrossRef]

19. Dorrell, R.G.; Azuma, T.; Nomura, M.; Audren de Kerdrel, G.; Paoli, L.; Yang, S.; Bowler, C.; Ishii, K.-I.; Miyashita, H.; Gile, G.H.; et al. Principles of plastid reductive evolution illuminated by nonphotosynthetic chrysophytes. Proc. Natl. Acad. Sci. USA 2019, 16, 6914-6923. [CrossRef] [PubMed]

20. Ševčíková, T.; Horák, A.; Klimeš, V.; Zbránková, V.; Demir-Hilton, E.; Sudek, S.; Jenkins, J.; Schmutz, J.; Přibyl, P.; Fousek, J.; et al. Updating algal evolutionary relationships through plastid genome sequencing: Did alveolate plastids emerge through endosymbiosis of an ochrophyte? Sci. Rep. 2015, 5, 10134. [CrossRef] [PubMed]

21. Archibald, J.M. Genomic perspectives on the birth and spread of plastids. Proc. Natl. Acad. Sci. USA 2015, 112, 10147-10153. [CrossRef] [PubMed]

22. Bodył, A. Did some red alga-derived plastids evolve via kleptoplastidy? A hypothesis. Biol. Rev. 2018, 93, 201-222. [CrossRef] [PubMed]

23. Burki, F. The Convoluted Evolution of Eukaryotes With Complex Plastids. In Advances in Botanical Research, 1st ed.; Elsevier Ltd.: Amsterdam, The Netherlands, 2017; pp. 1-30.

24. Oborník, M. The Birth of Red Complex Plastids: One, Three, or Four Times? Trends Parasitol. 2018, 34, 923-925. [CrossRef] [PubMed]

25. Baurain, D.; Brinkmann, H.; Petersen, J.; Rodríguez-Ezpeleta, N.; Stechmann, A.; Demoulin, V.; Roger, A.J.; Burger, G.; Lang, B.F.; Philippe, H. Phylogenomic evidence for separate acquisition of plastids in cryptophytes, haptophytes, and stramenopiles. Mol. Biol. Evol. 2010, 27, 1698-1709. [CrossRef]

26. Derelle, R.; López-garcía, P.; Timpano, H.; Moreira, D. A phylogenomic framework to study the diversity and evolution of stramenopiles (=heterokonts). Mol. Biol. Evol. 2016, 33, 2890-2898. [CrossRef]

27. Bouwmeester, K.; Van Poppel, P.M.J.A.; Govers, F. Genome Biology Cracks Enigmas of Oomycete Plant Pathogens. Annu. Plant Rev. Online 2009, 34, 102-133.

28. Del Campo, J.; Sieracki, M.E.; Molestina, R.; Keeling, P.; Massana, R.; Ruiz-Trillo, I. The others: Our biased perspective of eukaryotic genomes. Trends Ecol. Evol. 2014, 29, 252-259. [CrossRef]

29. Del Campo, J.; Massana, R. Emerging diversity within chrysophytes, choanoflagellates and bicosoecids based on molecular surveys. Protist 2011, 162, 435-448. [CrossRef]

30. Shiratori, T.; Thakur, R.; Ishida, K.-I. Pseudophyllomitus vesiculosus (Larsen and Patterson 1990) Lee, 2002, a poorly studied phagotrophic biflagellate is the first characterized member of Stramenopile environmental clade MAST-6. Protist 2017, 168, 439-451. [CrossRef]

31. Aleoshin, V.V.; Mylnikov, A.P.; Mirzaeva, G.S.; Mikhailov, K.V.; Karpov, S.A. Heterokont predator Develorapax marinus gen. et sp. nov.-A model of the ochrophyte ancestor. Front. Microbiol. 2016, 7, 1-14. [CrossRef]

32. Seeleuthner, Y.; Mondy, S.; Lombard, V.; Carradec, Q.; Pelletier, E.; Wessner, M.; Leconte, J.; Mangot, J.-F.; Poulain, J.; Labadie, K.; et al. Single-cell genomics of multiple uncultured stramenopiles reveals underestimated functional diversity across oceans. Nat. Commun. 2018, 9, 1-10. [CrossRef] 
33. Moestrup, $\varnothing$. Current status of chrysophyte 'splinter groups': Synurophytes, pedinellids, silicoflagellates. In Chrysophyte algae: Ecology, Phylogeny, Development; Sandgren, C., Smol, J.P., Kristiansen, J., Eds.; Cambridge University Press: Cambridge, UK, 1995; pp. 75-91.

34. Preisig, H.R. A modern concept of chrysophyte classification. In Chrysophyte algae: Ecology, Phylogeny, Development; Sandgren, C., Smol, J.P., Kristiansen, J., Eds.; Cambridge University Press: Cambridge, UK, 1995; pp. 47-74.

35. O'Kelly, C.J.; Patterson, D.J. The flagellar apparatus of Cafeteria roenbergensis Fenchel \& Patterson, 1988 (Bicosoecales = Bicosoecida). Eur. J. Protistol. 1996, 32, 216-226.

36. Karpov, S.A.; Kersanach, R.; Williams, D.M. Ultrastructure and 18S rRNA gene sequence of a small heterotrophic flagellate Siluania monomastiga gen. et sp. nov. (Bicosoecida). Eur. J. Protistol. 1998, 34, 415-425. [CrossRef]

37. Harder, C.B.; Ekelund, F.; Karpov, S.A. Ultrastructure and Phylogenetic Position of Regin rotiferus and Otto terricolus Genera et Species Novae (Bicosoecida, Heterokonta/Stramenopiles). Protist 2014, 165, 144-160. [CrossRef] [PubMed]

38. Guillard, R.R.L.; Ryther, J.H. Studies on marine planktonic diatoms I. Cyclotella nana (Hustedt) and Detonula confervacea (Cleve) Gran. Can. J. Microbiol. 1962, 8, 229-239. [CrossRef]

39. Guillard, R.R.L. Culture of phytoplankton for feeding marine invertebrates. In Culture of Marine Invertebrate Animals; Smith, W.L., Chanley, M.H., Eds.; Plenum Press: New York, NY, USA, 1975; pp. $29-60$.

40. Moore, R.B.; Oborník, M.; Janouškovec, J.; Chrudimský, T.; Vancová, M.; Green, D.H.; Wright, S.W.; Davies, N.M.; Bolch, C.J.S.; Heimann, K.; et al. A photosynthetic alveolate closely related to apicomplexan parasites. Nature 2008, 451, 959-963. [CrossRef]

41. Oborník, M.; Vancová, M.; Lai, D.H.; Janouškovec, J.; Keeling, P.J.; Lukeš, J. Morphology and ultrastructure of multiple life cycle stages of the photosynthetic relative of apicomplexa, Chromera velia. Protist 2011, 162, 115-130. [CrossRef] [PubMed]

42. Medlin, L.; Elwood, H.J.; Stickel, S.; Sogin, M.L. The characterization of enzymatically amplified eukaryotic 16S-like rRNA-coding regions. Gene 1988, 71, 491-499. [CrossRef]

43. Bolger, A.M.; Lohse, M.; Usadel, B. Trimmomatic: A flexible trimmer for Illumina sequence data. Bioinformatics 2014, 30, 2114-2120. [CrossRef]

44. Laetsch, D.R.; Blaxter, M.L. BlobTools: Interrogation of genome assemblies. F1000Research 2017, 1287, 1-16. [CrossRef]

45. Bankevich, A.; Nurk, S.; Antipov, D.; Gurevich, A.A.; Dvorkin, M.; Kulikov, A.S.; Lesin, V.M.; Nikolenko, S.I.; Pham, S.; Prjibelski, A.D.; et al. SPAdes: A New Genome Assembly Algorithm and Its Applications to Single-Cell Sequencing. J. Comput. Biol. 2012, 19. [CrossRef] [PubMed]

46. Simão, F.A.; Waterhouse, R.M.; Ioannidis, P.; Kriventseva, E.V.; Zdobnov, E.M. BUSCO: Assessing genome assembly and annotation completeness with single-copy orthologs. Bioinformatics 2015, 31, 3210-3212. [CrossRef] [PubMed]

47. Lowe, T.M.; Chan, P.P. tRNAscan-SE On-line: Integrating search and context for analysis of transfer RNA genes. Nucleic Acids Res. 2016, 44, W54-W57. [CrossRef] [PubMed]

48. Peabody, D.S. Translation Initiation at Non-AUG Triplets in Mammalian Cells. J. Biol. Chem. 1969, 264, 5031-5035.

49. Lohse, M.; Drechsel, O.; Kahlau, S.; Bock, R. OrganellarGenomeDRAW-A suite of tools for generating physical maps of plastid and mitochondrial genomes and visualizing expression data sets. Nucleic Acids Res. 2013, 41, 575-581. [CrossRef] [PubMed]

50. Kearse, M.; Moir, R.; Wilson, A.; Stones-Havas, S.; Cheung, M.; Sturrock, S.; Buxton, S.; Cooper, A.; Markowitz, S.; Duran, C.; et al. Geneious Basic: An integrated and extendable desktop software platform for the organization and analysis of sequence data. Bioinformatics 2012, 28, 1647-1649. [CrossRef] [PubMed]

51. Katoh, K.; Kuma, K.I.; Toh, H.; Miyata, T. MAFFT version 5: Improvement in accuracy of multiple sequence alignment. Nucleic Acids Res. 2005, 33, 511-518. [CrossRef] [PubMed]

52. Posada, D. jModelTest: Phylogenetic model averaging. Mol. Biol. Evol. 2008, 25, 1253-1256. [CrossRef]

53. Ronquist, F.; Teslenko, M.; Van Der Mark, P.; Ayres, D.L.; Darling, A.; Höhna, S.; Larget, B.; Liu, L.; Suchard, M.A.; Huelsenbeck, J.P. Mrbayes 3.2: Efficient bayesian phylogenetic inference and model choice across a large model space. Syst. Biol. 2012, 61, 539-542. [CrossRef] 
54. Rambaut, A.; Drummond, A.J. Tracer V1.5. Available online: http//beast.bio.ed.ac.uk/Tracer2009 (accessed on 5 August 2019).

55. Guindon, S.; Gascuel, O. A simple, fast, and accurate algorithm to estimate large phylogenies by maximum likelihood. Syst. Biol. 2003, 52, 696-704. [CrossRef]

56. Rambaut, A. FigTree v1.4.3. Mol. Evol. Phylogenetics Epidemiol. Available online: http://tree.bio.ed.ac.uk/ software/figtree/ (accessed on 5 August 2019).

57. Campelo, F.; van Galen, J.; Turacchio, G.; Parashuraman, S.; Kozlov, M.M.; García-Parajo, M.F.; Malhotra, V. Sphingomyelin metabolism controls the shape and function of the golgi cisternae. eLife 2017, 6, e24603. [CrossRef]

58. Tachikawa, M.; Mochizuki, A. Golgi apparatus self-organizes into the characteristic shape via postmitotic reassembly dynamics. Proc. Natl. Acad. Sci. USA 2017, 114, 5177-5182. [CrossRef]

59. Gruber, A.; Rocap, G.; Kroth, P.G.; Armbrust, E.V.; Mock, T. Plastid proteome prediction for diatoms and other algae with secondary plastids of the red lineage. Plant J. 2015, 81, 519-528. [CrossRef]

60. Bendtsen, J.D.; Nielsen, H.; Von Heijne, G.; Brunak, S. Improved prediction of signal peptides: SignalP 3.0. J. Mol. Biol. 2004, 340, 783-795. [CrossRef]

61. Ševčíková, T.; Klimeš, V.; Zbránková, V.; Strnad, H.; Hroudová, M.; Vlček, Č.; Eliáš, M. A comparative analysis of mitochondrial genomes in eustigmatophyte algae. Genome Biol. Evol. 2016, 8, 705-722. [CrossRef]

62. Griessmann, K. Uber marine Flagellaten. Arch. Protistenk 1913, 32, 1-78.

63. Larsen, J.; Patterson, D.J. Some flagellates (Protista) from tropical marine sediments. J. Nat. Hist. 1990, 24, 801-937. [CrossRef]

64. O'Kelly, C.J.; Nerad, T.A. Kinetid architecture and bicosoecid affinities of the marine heterotrophic nanoflagellate Caecitellus parvulus (Griessmann, 1913) Patterson et al., 1993. Eur. J. Protistol. 1998, 34, 369-375.

65. Andersen, R.A. Synurophyceae classis nov., a new class of algae. Am. J. Bot. 1987, 74, 337-353. [CrossRef]

66. Andersen, R.A. The cytoskeleton of chromophyte algae. Protoplasma 1991, 164, 143-159. [CrossRef]

67. Dzeja, P.P.; Bortolon, R.; Perez-Terzic, C.; Holmuhamedov, E.L.; Terzic, A. Energetic communication between mitochondria and nucleus directed by catalyzed phosphotransfer. Proc. Natl. Acad. Sci. USA 2002, 99, 10156-10161. [CrossRef]

68. Al-Mehdi, A.-B.; Pastukh, V.M.; Swiger, B.M.; Reed, D.J.; Patel, M.R.; Bardwell, G.C.; Pastukh, V.V.; Alexeyev, M.F.; Gillespie, M.N. Perinuclear Mitochondrial Clustering Creates an Oxidant-Rich Nuclear Domain Required for Hypoxia-Induced Transcription. Sci. Signal. 2012, 5, 1-20. [CrossRef]

69. Picard, M. Mitochondrial synapses: Intracellular communication and signal integration. Trends Neurosci. 2015, 38, 468-474. [CrossRef]

70. Prachař, J. Intimate contacts of mitochondria with nuclear envelope as a potential energy gateway for nucleo-cytoplasmic mRNA transport. Gen. Physiol. Biophys. 2003, 22, 525-534.

71. Delprat, B.; Rieusset, J.; Delettre, C. Defective Endoplasmic Reticulum-Mitochondria Connection Is a Hallmark of Wolfram Syndrome. Contact 2019, 2, 251525641984740. [CrossRef]

72. Rowland, A.A.; Voeltz, G.K. Endoplasmic reticulum-mitochondria contacts: Function of the junction. Nat. Rev. Mol. Cell Biol. 2012, 13, 607-615. [CrossRef]

73. Elbaz, Y.; Schuldiner, M. Staying in touch: The molecular era of organelle contact sites. Trends Biochem. Sci. 2011, 36, 616-623. [CrossRef]

74. Friedman, J.R.; Lackner, L.L.; West, M.; DiBenedetto, J.R.; Nunnari, J.; Voeltz, G.K. ER tubules mark sites of mitochondrial division. Science 2011, 334, 358-362. [CrossRef]

75. Salazar-Roa, M.; Malumbres, M. Fueling the Cell Division Cycle. Trends Cell Biol. 2017, 27, 69-81. [CrossRef]

76. Hancock, K.; Jahduk, S.L. The mitochondrial tRNAs of Trypanosoma brucei are nuclear encoded. J. Biol. Chem. 1990, 265, 19208-19215.

77. Tan, T.H.P.; Pach, R.; Crausaz, A.; Ivens, A.; Schneider, A. tRNAs in Trypanosoma brucei: Genomic organization, expression, and mitochondrial import. Mol. Cell. Biol. 2002, 22, 3707-3717. [CrossRef] [PubMed]

78. Zabezhinsky, D.; Slobodin, B.; Rapaport, D.; Gerst, J.E. An essential role for COPI in mRNA localization to mitochondria and mitochondrial function. Cell Rep. 2016, 15, 540-549. [CrossRef] [PubMed]

79. Michaud, M.; Maréchal-Drouard, L.; Duchêne, A.M. Targeting of cytosolic mRNA to mitochondria: Naked RNA can bind to the mitochondrial surface. Biochimie 2014, 100, 159-166. [CrossRef] 
80. Fogarty, N.M.E.; Ferguson-Smith, A.C.; Burton, G.J. Syncytial knots (Tenney-parker changes) in the human placenta: Evidence of loss of transcriptional activity and oxidative damage. Am. J. Pathol. 2013, 183, $144-152$. [CrossRef] [PubMed]

81. Liu, X.; Weaver, D.; Shirihai, O.; Hajnóczky, G. Mitochondrial kiss-and-run: Interplay between mitochondrial motility and fusion-fission dynamics. EMBO J. 2009, 28, 3074-3089. [CrossRef] [PubMed]

82. Giorgi, C.; Missiroli, S.; Patergnani, S.; Duszynski, J.; Wieckowski, M.R.; Pinton, P. Mitochondria-Associated Membranes: Composition, Molecular Mechanisms, and Physiopathological Implications. Antioxid. Redox Signal. 2015, 22, 995-1019. [CrossRef] [PubMed]

83. Campelo, F.; Arnarez, C.; Marrink, S.J.; Kozlov, M.M. Helfrich model of membrane bending: From Gibbs theory of liquid interfaces to membranes as thick anisotropic elastic layers. Adv. Colloid. Interface Sci. 2014, 208, 25-33. [CrossRef] [PubMed]

(C) 2019 by the authors. Licensee MDPI, Basel, Switzerland. This article is an open access article distributed under the terms and conditions of the Creative Commons Attribution (CC BY) license (http://creativecommons.org/licenses/by/4.0/). 